\title{
SECURITY ASPECTS OF REGIONAL COOPERATION IN CENTRAL EUROPE: VISEGRÁD GROUP, BUCHAREST NINE, AND THE THREE SEAS INITIATIVE
}

\author{
Agnieszka ORZELSKA-STACZEK, PhD \\ Institute of Political Studies, Polish Academy of Sciences, Poland \\ aorzel@isppan.waw.pl
}

Piotr BAJDA, PhD

Institute of the Political Science and Administration Studies, Poland p.bajda@uksw.edu.pl

\begin{abstract}
This article investigates the role of security in the development of regional cooperation in Central Europe. The main research question concerns the correlation between the security environment and the development of regional cooperation. We argue that the numerous forms of regional cooperation were created to consolidate states in narrow or wider constellations, so as to better protect their security interests. Regional cooperation has a significant, albeit complementary, place in the European security architecture, which is based on the transatlantic community. Empirically, the paper delves into the Visegrád Group (V4), the Three Seas Initiative (3SI) and the Bucharest Nine (Bucharest format, B9). Its theoretical and methodological approach is based on the transition paradigm, which in its security dimension still sets the framework for research on post-communist countries and gives a good insight into the development of regional cooperation in Central Europe. We also refer to the cooperation patterns of small states, taking into consideration the geopolitical restraints caused by their location between great powers. Our research is predominantly based on realist theory. Therefore, we emphasize the significance of threats, state interests, and changes in the international order. We use qualitative research methods, in particular content analysis of documents and the results of a project based on data collection techniques through interviews with diplomats from 3SI states.
\end{abstract}

Keywords: Security, Regional cooperation, Central-Eastern Europe, Three Seas Initiative, Bucharest Nine, Visegrád Group, New regionalism, Transition paradigm, Transformation.

\section{Introduction}

During two waves of new regionalism in Central Europe-the first at the beginning of the 1990s, the second after 2014—many loose forms of cooperation were set up. The dynamic 
development of regional cooperation was accompanied by profound changes in the security environment.

This article investigates the security aspects of cooperation between Central European states. The main research question concerns the correlation between changes in the security environment and the development of regional cooperation. We argue that the numerous forms of regional cooperation were created to consolidate states in narrow or wider constellations, so as to better protect their security interests. Regional cooperation has played a significant role in shaping the European security architecture. This role, however, is complementary, since Central European state security is based on the transatlantic community, with NATO and the EU constituting the uncontested pillars.

Regional cooperation in Central Europe has gained increasing scholarly attention in recent studies. Scholars mostly focus on the political, economic, and infrastructural dimensions of cooperation, marginalizing its security aspects. This study contributes to filling the research gap.

We define the concept of security according to realist theories, which emphasize the preservation of a state's territorial integrity and the physical safety of its inhabitants. ${ }^{1}$ We stress the importance of military security, but we also consider energy security, economic security, and cybersecurity. When examining regional cooperation, we focus on loose forms of groupings set up in Central Europe since the end of the Cold War. These do not function on the basis of an international agreement; they were created functionally during the process of organizing cooperation, which makes them less transparent. Empirically, the paper delves into the Visegrád Group, the Three Seas Initiative (3SI), and the Bucharest Nine (Bucharest format, B9). These were selected as relevant examples to illustrate specific features of regional cooperation and their correlation with security.

Our theoretical and methodological approach is based on the transition paradigm, which in its security dimension still sets the framework for research on post-communist countries and gives a good insight into the development of regional cooperation in Central Europe. Many scholars have investigated the transition paradigm, focusing on interior policy and economic and social transition (Grzymski, 2016; Kollmorgen, 2013; Staniszkis, 1999; Fedorowicz, 2017). In contrast,

1 Stephen M. Walt (2010) notes that “A state is thought to be secure if it can defend against or deter a hostile attack and prevent other states from compelling it to adjust its behavior in significant ways or to sacrifice core political values.” 
this article is based on the foreign and security policy dimension of the transition paradigm. This is a new approach to regional cooperation among Central European states.

Following the classical realist approach, we treat Central European states as the primary actors, which participate in regional cooperation to pursue their national interests. We argue that security was a significant motivator for them to cooperate in the face of new threats, including military threats. Using the assumptions of neorealist theory, we stress the significance of global changes for the behavior of this group of mostly small states, particularly at the beginning of the transition period. Therefore, we also refer to small states' cooperation patterns and take into consideration the geopolitical restraints caused by their location between great powers (Bajda, 2018). Central European states are divided by many unresolved historical issues, and in many areas they are prone to compete rather than cooperating. Referring to contingent realism, we agree that "structural realism properly understood predicts that, under a wide range of conditions, adversaries can best achieve their security goals through cooperative policies” (Glaser, 1994). We use qualitative research methods, particularly content analysis of documents and the results of a project based on data collection techniques through interviews with diplomats from 3SI states. ${ }^{2}$

The first section of the article investigates regional cooperation in the transition paradigm. This is followed by two empirical sections, concerning the first wave of new regionalism in Central Europe in the early 1990s and the second wave after 2014. In both sections we elaborate on the main findings of the article by discussing security aspects of the V4, 3SI, and B9. Finally, we present our conclusions and possible avenues for further research.

\section{Regional cooperation in the transition paradigm}

The period of transition from communism to democracy in Central Europe began in 1989. After the dissolution of the Soviet bloc, Central European states strove to become part of the West through joining the EU and NATO. In this narrow sense, the transition period ended with the enlargement of the EU and NATO. This, however, did not remove the deep divisions between eastern and western parts of Europe. The perception of Central European states as less developed and less democratic than those in Western Europe remains valid. Despite profound changes at the

\footnotetext{
2 The project was carried out at the Institute of Political Studies, Polish Academy of Sciences in 2019-2020. The results of the research, as well as complete interviews with ambassadors from 3SI states and the head of the Polish President's Office, have been published (Orzelska-Stączek \& Ukielski, 2020).
} 
international level that have been underway for more than a decade since the EU and NATO's biggest enlargement, the dichotomy is still used between the "fully European" part of the EU and the "insufficiently European" part; the latter embracing "new" European states, especially Poland and Hungary, which need "Europeanization”. The European Union remains divided between Western Europe and a peripheral part called Central or Central-Eastern Europe (Kowal \& Orzelska-Stączek, 2019).

The transition paradigm in the field of the foreign and security policy of Central European states is based on two core assumptions. ${ }^{3}$ The first stresses their striving for consolidation with the West; the second focuses on their resilience to Russian pressure. While Central European states were moving away from dictatorial rule toward democracy, they also deeply reoriented their foreign and security policies after a few decades of Soviet domination in the region. They treated the USSR and its successor Russia as an influential actor and as a source of threat for the region, although they differed in their perceptions of the scale of the threat. Regardless of differences, this mosaic group of mostly small powers decided to strengthen ties with a strong transatlantic community, with special roles for NATO and EU and an active presence in Europe for the USA as the foremost world power. This option was accepted as their best security guarantee.

The transition paradigm in the field of foreign and security policy retains its explanatory power, showing that Central European states are still following their characteristic behavior patterns from the first years of transition. The threat posed by Russia remains a major security concern in the region, although states differ in their approach to Russia. Undoubtedly, they still consider NATO to be the main guarantor of their security. Their priority is to be fully integrated into the West, not only in legal terms, but also in the political and economic spheres. At present, although they have the legal status of NATO and EU members, in many ways they are perceived not as part of the West, but rather the East of the West.

From the neorealist perspective, the new regionalism in Central Europe played a subsidiary role in achieving the states' foreign and security policy priorities, namely integration with the West. Central European states were located in an unstable area of rivalry between great powers. In face of the new threats, no Central European state had either the potential or the motivation to consolidate the region as an autonomous unit and guarantee its security.

3 In a broad approach, Thomas Carothers (2002) notes that "Five core assumptions define the transition paradigm. The first, which is an umbrella for all the others, is that any country moving away from dictatorial rule can be considered a country in transition toward democracy.” 
The first and second waves of new regionalism in Central Europe each followed the same pattern: states set up loose forms of cooperation. None of the new regional cooperation forms had the status of an international political organization. Nor did the Visegrád Group (set up in 1991), the Three Seas Initiative (2016), or the Bucharest Nine (2015), have statutes, secretariats or permanent structures. ${ }^{4}$ In a sense, they were flexible substitutes for organizations, based on nonlegally-binding declarations and described vaguely as "a cooperation forum,” "a political lobby group," “an informal grouping," “a cooperation structure,” or "an informal regional forum for the cooperation of countries.”

To be precise, the B9 defined itself as an "open platform of consultations and dialogue” (Bucharest Nine, 2015). The main declared purpose of the B9 was to strengthen transatlantic security through strengthening NATO’s eastern flank. It was not specified how exactly this aim would be achieved. In its first declaration adopted in Dubrovnik, the 3SI presented itself as "an informal platform for securing political support and decisive action on specific cross-border and macro-regional projects of strategic importance to the States involved” (Three Seas Initiative, 2016). In practice, it was an example of summit diplomacy, based on annual summits of the heads of states. The Visegrád Group has certain narrow institutional frames (e.g., a presidency, the V4 plus format) but it does not have statutes, a headquarters, a secretariat, or formal accession criteria (Orzelska-Stączek, 2019, p.118).

We should note that Yugoslavia was a communist state, but after the 1948 YugoslaviaSoviet split it was not a part of the Soviet Bloc. Austria is also exceptional among 3SI states: it remained under joint occupation by the Western Allies and the Soviet Union until 1955, did not belong to the Soviet Bloc, was not a communist state and did not go through transition. While the transition paradigm explains well the behavior of the post-communist countries, it does not apply to Austria.

\section{First wave of new regionalism: the 1991 Visegrád Group and its security aspects}

Poland, Hungary, and Czechoslovakia (until 1993, when it split into the Czech and Slovak Republics) entered the process of rapid transformation at the end of 1989. The collapse of the Soviet Bloc and, consequently, the changing situation in the international arena resulted in a huge

\footnotetext{
${ }^{4}$ The Visegrád Fund and the Three Seas Initiative Investment Fund both exist, but they are separate financial institutions.
} 
challenge in the area of security, mobilizing the first non-communist leaders in Central Europe to seek new regional arrangements. The weakness of the Soviet Union allowed Warsaw, Prague, and Budapest to regain sovereignty, defined in terms of classical realism as independence from the power of other international players and equality of states under international law (Czaputowicz, 2018, p. 183). This did not, however, mean immediately cutting all ties with Moscow (for example, at the beginning of 1990, the Warsaw Pact was officially still in existence); still less obtaining an offer of immediate integration into Western European structures. Central European states found themselves in a security gray zone. It is worth recalling that one scenario considered at that time was Henry Kissinger's plan for Central European post-communist states to declare neutrality, which was to be guaranteed jointly by NATO and Russia. ${ }^{5}$ At the same time, the Federal Republic of Germany, which had traditionally been active in the region, was preoccupied with obtaining the great powers' consent for the project of German unification.

In this atmosphere of uncertainty, Central European states themselves had to seek instruments to strengthen their international position, and above all, their security. In November 1989, the Quadragonale was created in Budapest between Hungary, Yugoslavia, Italy, and Austria. After the Velvet Revolution in Czechoslovakia in November 1989 and the appointment of the playwright and former oppositionist Václav Havel to the office of president, Prague sought to take the initiative in the region. A conference organized by Havel in April 1990 discussed the idea of extending Central European cooperation. The result was the admission of Czechoslovakia to the Quadragonale, creating the Pentagonale. ${ }^{6}$ A curious facet of these decisions was an attempt to leave Poland on the sidelines in consolidating the region. Havel (1990), for example, proposed to assign Poland the role of a Northern European country, whose interests should be focused around the Baltic Sea basin.

However, the low involvement of Vienna and Rome and, above all, the break-up of Yugoslavia forced the region's leaders to seek new, more local solutions. As a result of diplomatic consultations, the Visegrád Group (since the division of Czechoslovakia in 1993, the Visegrád Four or V4) was established in February 1991. It remains the most recognizable symbol of cooperation between Central European states. The V4 was a regional arrangement of a new type.

\footnotetext{
${ }^{5}$ For more on Kissinger’s proposal, see Riekhoff (2004, p. 56).

${ }^{6}$ The Pentagonale format has gradually expanded; today it is the Central European Initiative with its own budget and a secretariat executive in Trieste. For details, see https://www.cei.int/secretariat.
} 
The title of its founding document, Declaration on Cooperation between the Czech and Slovak Federal Republic, the Republic of Poland and the Republic of Hungary in Striving for European Integration, emphasized that the main goal of the project was external; its motto was "the return to Europe”. The second characteristic feature of the V4 group, which also fitted in with the new regionalism, was the assumed lack of institutionalization of the new initiative, designed to avoid even the appearance of competing with the organizations the V4 states sought to join. In this context, the Visegrád Group was to be a regional arrangement whose priority was to strengthen the political position of individual Central European states in their efforts to obtain membership of the European Union and NATO. Thus, from the very beginning, the V4 played a subsidiary role in relation to the strategic goals of firm consolidation of Central Europe into Euro-Atlantic institutions.

The V4 group is a pragmatic instrument. It has tried to animate political and economic cooperation, ${ }^{7}$ but has also touched security issues. This dimension has been largely ignored by researchers, who have focused on political cooperation, the dynamics and durability of which to a large extent depend on bilateral relations between the four countries. However, the presence of security in most of the V4's strategic documents, as well as in the programs of individual presidencies, proves that the security dimension has been a significant part of V4 activity. Security was mentioned in the Visegrád Declaration (1991); it was to be achieved through full integration with Western political institutions, complemented by close cooperation among the signatories. ${ }^{8}$ Since 1999, the defense ministers of all four countries have regularly met in the V4 format, along with the presidents and heads of government. The first consultations of this kind took place in Przemysl in November 1999. They concerned, firstly, the principles of consultation and cooperation after Czech, Hungarian, and Polish accession into NATO; and secondly, an action plan to support Slovakia's efforts to be invited to join NATO. Defense cooperation was also emphasized in the second of the most important Visegrád documents, summing up the meeting of the V4 prime ministers on May 12, 2004 in Kroměříž - that is, a few days after the great enlargement of the European Union. The final declaration indicated defense as one of the main

\footnotetext{
${ }^{7}$ An expression of this pragmatism was the establishment of the Central European Free Trade Agreement (CEFTA) in December 1992, aiming to boost trade in the region, but also to prepare for EU membership. To this day, CEFTA is an organization of countries aspiring to EU membership: https://cefta.int/.

8 “The signatories of the Declaration shall jointly undertake the following practical steps: in accordance with the interests of the particular countries they shall harmonize their activities to shape cooperation and close contacts with European institutions and shall hold regular consultations on the matters of their security” (Visegrád Group, 1991).
} 
pillars of Visegrád cooperation, in three dimensions: coordination within the V4, cooperation within the multilateral structures of NATO and the EU, and promotion of NATO expansion to include other Central European countries in order to expand the security area (Visegrád Group, 2004).

An important modus operandi of the V4 states involves attempting to work out common positions before meetings in the wider multilateral arena, so as to influence decision-making processes. As a result, numerous consultations of V4 foreign and defense ministers have taken place before NATO summits. April 2012 saw the adoption of the V4 declaration "Responsibility for a Strong NATO,” which expressed support for admitting new members and stressed that capability development in NATO and the EU must be mutually supportive in order to avoid duplication (Visegrád Group, 2012a). A month later, the Joint Communiqué of the Ministers of Defense of the Visegrád Group highlighted the V4's contribution to building security architecture by creating the Visegrád Group European Union Battlegroup; it also pointed to a whole range of joint undertakings for European operations (Visegrád Group, 2012b). These were organized ahead of the NATO summit in Chicago.

The Visegrád Group’s activities so far have focused most clearly on political cooperation; first on accelerating the integration processes with the EU and NATO, and later on strengthening the Group's position in the European forum. While the V4 itself has a supportive role in achieving these strategic goals, cooperation in the field of security has a more intra-regional character. Worth emphasizing here are the actions aimed at supporting Slovakia's aspirations on the path to NATO membership. ${ }^{9}$

\section{The second wave of new regionalism as a response to a deterioration in the security environment}

In 2014, the European security architecture fundamentally changed. Russia effectively carried out an aggressive policy, below the threshold of a classic war, which led to the annexation of Crimea without declaring war on Ukraine. Soldiers participated in the military operation without

\footnotetext{
9 For reasons of internal policy, Slovakia was excluded from the first group of Central European countries invited into the EU and NATO in 19941998. As a result, Bratislava became a member of the North Atlantic Alliance only in the second wave of enlargement in 2004. For more information, see Bajda (2013).
} 
being identified as such, and in the information chaos it was difficult to discern what was happening. This type of conflict, called hybrid warfare, ${ }^{10}$ eludes classical definitions of war. The swift and victorious campaign took the world by surprise and appeared especially impressive as it stood in contrast to the failures of past Russian military interventions (Renz, 2016; OrzelskaStączek, 2015). The strategic factor of surprise was important in enabling Russian success not only in Crimea, but also in destabilizing Ukraine. The West's weak response to Russia's aggressive policy for domination over ex-Soviet territories overlapped with a multifaceted crisis in the Western world.

The deteriorating security environment in Central Europe since 2014 is not only a product of Russian revisionism. Other challenges have concerned tensions in transatlantic relations and a crisis of the European integration project. The EU struggled with an economic and migration crisis and was weakened by Brexit, initiated by referendum in 2016. Whether defined as "soft," "normative” or “transformative” power, the EU’s power was declining (Dimitrova et al., 2016; Webber, 2016). The deterioration in the security environment was a direct incentive for Central European states to undertake diplomatic efforts to initiate new forms of regional cooperation.

The correlation between the security architecture changes in 2014 and the emergence of new forms of cooperation was most explicitly illustrated by the Bucharest Nine (Bucharest format, B9). The joint declaration "Allied Solidarity and Shared Responsibility," which is regarded as the B9's founding document, was adopted in the Romanian capital in November 2015. The representatives of nine countries ${ }^{11}$ of NATO's eastern flank took this step in order to improve their security cooperation within the Alliance. The three-page declaration refers 14 times to "security" and 7 times to "threat". In contrast, the Three Seas Initiative annual summit declarations have not mentioned security matters, apart from references to energy security. ${ }^{12}$ But as 3SI cooperation has developed, the scope of its security interests has increased.

There have been other regional cooperation initiatives that are outside the scope of our research. It is worth mentioning the Lublin Triangle founding declaration, adopted in 2020 by Poland, Lithuania, and Ukraine, almost entirely focused on security issues in the context of Russian

\footnotetext{
10 The concept of "hybrid warfare” is gaining popularity, but there is also a rich literature critical of the concept. See Renz (2016).

11 The Presidents of Bulgaria, Estonia, Hungary, Latvia, Lithuania, Poland, Romania, and the Slovak Republic, and the President of the Chamber of Deputies of the Parliament of the Czech Republic.

12 The Three Seas Initiative annual summit declarations from 2016 to 2020: https://3seas.eu/about/past-summits. See also Orzelska-Stączek (2020).
} 
aggression. Security also appeared in the Slavkov declaration, adopted on January 29, 2015, by the heads of government of the Czech Republic, the Republic of Austria, and the Slovak Republic, which gave rise to the Slavkov Triangle (the Austerlitz format). This short document focused on fostering growth and employment, but also addressed the situation in Eastern Ukraine and the external challenges faced by EU members, including the fight against terrorism (Austerlitz Declaration, 2015).

\section{The Visegrád Group after 2014}

Steps towards closer defense cooperation among the V4 had already been taken in 2008 after the NATO summit in Bucharest and Russian aggression against Georgia. This trend accelerated after the Russian annexation of Crimea in March 2014. In response to questioning of the existing security architecture, the V4 defense ministers drew up two documents on strengthening their cooperation: the Long Term Vision of the Visegrád Countries on Deepening Their Defense Cooperation and the Framework for an Enhanced Visegrád Defense Planning Cooperation. Both documents emphasized the need for in-depth cooperation between V4 countries in NATO and the EU in the area of security. The V4 Planning Group, with designated State Secretaries supported by expert groups, was also created (Visegrád Group, 2014). In a meeting the following year, the V4 defense ministers appealed to the Long Term Vision of the Visegrád Countries on Deepening Their Defense Cooperation, indicating the country that now posed the greatest threat: "Russia’s aggressive actions against Ukraine as well as provocative activities along the eastern border of NATO have profoundly challenged the security architecture in our region" (Visegrád Group, 2015). Although the Czech Republic, Slovakia, and Hungary declared that they were not interested in hosting NATO soldiers under the enhanced Forward Presence program, they fully supported the Polish position on the need to strengthen the eastern flank. The communiqué from the V4 Defense Ministers' meeting of 2017 stated, “We stressed that the recent deployment of the US Armored Brigade Combat Team to Poland is of importance for ensuring the security of the entire region and the strength of the transatlantic link” (Visegrád Group, 2017) Two years later, a decision was made to further tighten cooperation by establishing the Joint Logistic Support Group Headquarters V4 (Visegrád Group, 2019).

There is controversy surrounding the functioning of the V4, with some accusing Central European countries of breaking EU solidarity in the face of the migration crisis (Zachova et al., 
2018). Despite such criticism, the V4 has become a symbol of the revived Central Europe concept and a commonly used collective name for the four countries involved, as indicated for example by the titles of works by J. Fitzmaurice (1998) or E.J. Kirchner (1999). The Visegrád Group consistently focuses some of its attention on activities broadly related to security and tries to make a positive contribution, for example by establishing the V4 Battlegroup (first combat duty JanuaryJune 2016), and coordinating positions before the meetings of wider multilateral forums (the EU and NATO). No less important, it is an advocate and the main promoter of the alliance's opendoor policy for Central European countries. The V4 has reacted flexibly to threats to security in the region.

The Visegrád Group was originally intended to become an element of the new security architecture in the region, establishing political cooperation without the great powers engagement. It contributed to the acceleration of the dissolution of the Warsaw Pact. However, a more important result was the creation of a regional arrangement, which over the years has acquired a specific identity, gained the ability to influence its immediate environment, and above all, revived the concept of Central Europe in the political debate. The Visegrád Group, with its activity and initiatives, has become part of the new regionalism, the activities of which are subsidiary to global processes (Hettne \& Söderbaum, 2000).

The V4 is not a popular topic in global scientific literature. When it is mentioned at all, it is in texts on the issues of political cooperation or the functioning of Central European states within the European Union. The lack of recognition of the security dimension in the activities of the Visegrád Group may be due to the fact that it is primarily of an internal nature. At present the most visible effect is the V4 EU Battlegroup, which was on duty January-June 2016. The functioning of the V4 EU Battlegroup may, in future, draw the attention of more researchers to this dimension of cooperation between Central European countries. The intra-regional character of V4 defense cooperation also includes joint exercises and organization of training centers.

The Bucharest Format and the Three Seas Initiative have the potential to significantly complement the European security architecture. Among numerous Central European regional arrangements, B9 is the only format specifically set up to improve security cooperation. It comprises 9 of the 29 NATO members (Poland, Romania, Estonia, Lithuania, Latvia, Slovakia, the Czech Republic, Hungary, and Bulgaria), including all the Visegrád states, and focuses on 
military consultation within NATO. All B9 participants also take part in the Three Seas Initiative, which consists of 12 of the 27 EU member states. The 3SI mainly supports pragmatic cooperation in the development of transport, energy infrastructure, and technology. It is important to note that the Three Seas Initiative also includes Austria, which stands out from the rest of the group as is neither a part of B9, nor a NATO member and is traditionally associated with Western Europe.

The main threats indicated in the B9 founding declaration concerned the volatility of the global security situation and aggressive Russian military activities, which were undermining the European security architecture (Bucharest Nine, 2020; Rogozińska, 2019). Some of the B9 states (Poland, Romania, Lithuania, Latvia, Estonia) perceived Russia as a military threat; the others (Czechia, Slovakia, Hungary, Bulgaria) took a different view, but they all acknowledged NATO as a pillar of European security and sought common positions that would strengthen the role of Central Europe during the NATO adaptation process (Pieńkowski, Raś, Ogrodnik, Terlikowski, \& Jóźwiak, 2018). The USA declared support for B9 and the 3SI; this support enhanced the security contextualization of these forms of regional cooperation. ${ }^{13}$

The loose formula of the V4, 3SI, and B9 was chosen by the participating states as optimal. In spite of certain drawbacks, it had the benefits of flexibility, without creating legal obligations or permanent structures. Most importantly, it evaded criticism of alleged attempts to build organizations in Central Europe that would rival or split the EU. Such a narrative would be against the security interests of Central European states and their efforts to reinforce the region only within the Euro-Atlantic framework.

The B9 has significant potential to shape the NATO agenda. Most of the B9 states are firmly committed to taking on an increased burden in NATO by increasing their defense expenditures. Their declared priorities are to contribute to common security, maintain cohesion, and build the credibility of Allied defense and deterrence. Their increasing role in NATO burden sharing shows that they are also trying to change how they are perceived, from security consumers to security generators. The most important constraints on the B9 concern differing national threat perceptions, uneven commitments to investment in defense capabilities, and the potential volatility of military modernizations (Pieńkowski et al., 2018).

\footnotetext{
13 The Estonian ambassador to Poland, Martin Roger, said in 2018: "The USA is a catalyst for the 3SI and has given further political impetus to the format. The US administration has been very positive about the 3SI. The USA's increased presence in the region is good for security” (OrzelskaStączek \& Ukielski, 2020).
} 
While the B9 is clearly focused on security, the security relevance of the 3SI is more complex. This form of cooperation is closely related to the economic and infrastructural development of Central European states. However, there are various approaches to its political and security implications. We argue that the 3SI's significance for security is increasing as the cooperation develops. The first declaration of the 3SI stated in general terms that "by expanding the existing cooperation in energy, transportation, digital communication and economic sectors, Central and Eastern Europe will become more secure [and] safe” (Three Seas Initiative, 2016). The Bucharest 3SI declaration referred to energy security and building a more prosperous, united, and secure European Union. In the Ljubljana declaration (Three Seas Initiative, 2019), we read that the 3SI contributes to security and that energy, infrastructure, and digitalization, as well as the crosscutting topics of security, innovation, and the environment, are essential to the future of the region. The 3SI Joint Statement adopted in Tallin (Three Seas Initiative, 2020) notes that regional economic development will increase the social cohesion and resilience of the European Union, contributing to the strengthening of Central European regional security. The aims of the 3SI, as formulated by Estonia as the host of the 2020 summit, put a stronger emphasis on security; the list includes "economic growth, security and a stronger and more cohesive Europe." ${ }^{14}$ According to its official website, the 3SI is not only intended to boost energy security: in terms of geopolitics, strong economic development will help to more effectively defend current geopolitical interests.

The security aspect was also present in interviews conducted in 2019 with 3SI states' ambassadors to Poland. Most of the ambassadors referred in general terms to aspects of security, energy security, and cybersecurity (Orzelska-Stączek \& Ukielski, 2020). ${ }^{15}$ For example, the Romanian Ambassador noted that the "3SI aims to contribute to enhancing economic resilience in Central and Eastern Europe, a goal with strategic relevance as well, while turning the region into a focal point for NATO and EU strategic convergence and a strategic contributor to the collective defense and prosperity of the Euro-Atlantic community.” In his opinion, 3SI and B9 are flexible formats of cooperation among European countries from a certain geographic area with similar security perceptions and common economic interests and challenges. These similarities, stressed by many respondents, may be well explained by the transition paradigm.

\footnotetext{
14 See https://3seas.eu/about/objectives.

15 There was no reference to security in the interviews with the ambassadors from Austria and Slovenia.
} 
One of the main achievements of the 3SI is the development of a list of priority multilateral projects. With the support of the 3SI Fund, these are the key instrument to implement its ambitious ideas. The flagship 3SI investment is the Via Carpathia, which along with other infrastructure investments is to be a "Tri-Sea transport spine-pillar." Such transport investments are also important for military mobility. For example, the Rail-2-Sea: "Modernization and development of railway line Gdansk(PL)-Constanța (RO)" is presented as a civil-military dual-use project (Three Seas Initiative, 2018). Many other 3SI projects have similar potential, although they are not explicitly described as such. Minister K. Szczerski from the Cabinet of the President of Poland has pointed out that military mobility is a common EU and NATO priority; transport infrastructure appeared as essential for military mobility in the context of the Three Seas Initiative after the NATO summit in Warsaw in 2016 (Orzelska-Stączek \& Ukielski, 2020).

The implementation of 3SI infrastructure projects will have a significant impact on the security environment of the region. There are several aspects to this. Firstly, 3SI cooperation concerns energy security. The diversification of gas supply may be an effective response to the construction of the gas pipeline Nord Stream 2, which is a clear example of conflicting interests in the region. Most Central European states remain heavily dependent on Russian gas. The security implications of Nord Stream 2 relate not only to energy; they also challenge Central European states' gas market development, planned gas prices, their transit roles, and their security in general (Łoskot-Strachota, Bajczuk, \& Kardaś, 2018; Jakóbik, 2018; Ruszel, 2018; Kardaś, 2018; Congressional Research Service, 2020). Secondly, the planned infrastructure investments aim to facilitate military mobility in the region. Thirdly, the development of digital infrastructure should strengthen European capabilities in the field of cybersecurity. From a broader perspective, the 3SI aims at strengthening links with the USA, therefore consolidating the transatlantic community and its security. Some diplomats even wish the 3SI to serve as a bridge linking the USA and Europe. However, there is some controversy over this issue, which overlaps other challenges in transatlantic relations. Also unresolved is the issue of the impact of the 3SI on the EU. Initially, the EU and German approaches towards the 3SI were unclear. In 2017, the United States and Germany gained the status of 3SI partner states, and the EU of a partner institution, which gave a new impetus to the development of cooperation. Despite this, some uncertainty remains over EU and German attitudes to the 3SI. 


\section{Conclusions}

Initially, regional cooperation in Central Europe consisted mainly of attempts to coordinate political and economic positions, aiming at integration with the European Union. Consolidation of the states in the region was of crucial importance on their way to the EU and NATO, which constituted the states' security policy priority. The global changes of the security architecture have been recognized as a challenge for Central Europe, particularly at the beginning of the transition period in the 1990s and then in the face of the Russian annexation of Crimea and the destabilization in Ukraine in 2014. The latter set of events led to the second wave of regional self-organization in the form of new regional arrangements, including the Bucharest Nine and the Three Seas Initiative, the latter of which has featured projects with dual civil-military applications. There has been a significant correlation between changes in the security environment and the development of regional cooperation in Central Europe.

Our research into the various forms of cooperation between Central European states indicates that they were launched as a result of decisions made by the region's leaders in the face of a changing geopolitical situation. Therefore, neorealist theory is most useful for investigating these developments. However, the theory itself does not explain the specificity of the new regionalism in Central Europe, which is characterized by limited forms of institutionalization. The key to understanding these processes is the transition paradigm, which has allowed us to explore the issue. The usefulness of this paradigm reveals its exploratory possibilities, helping us to understand the specific characteristics of Central Europe and its methods of self-organization after 1989. This study should therefore be treated as an introduction to further studies on the transition paradigm, as a tool for understanding international relations in Central Europe.

\section{Disclosure statement}

No potential conflict of interest was reported by the authors. 


\section{References}

1. Austerlitz Declaration. (2015). https://www.vlada.cz/assets/mediacentrum/aktualne/Austerlitz-Declaration.pdf.

2. Bajda, P. (2013). The Visegrád Group between the Trade-Mark and the political organization of the peripheral countries. In J. Marušiak et al. (Eds.), Is Visegrád Still a Central European “Trade Mark”? (pp. 30-33), Bratislava. Institute of Political Science, Slovak Academy of Sciences - VEDA, Publishing House of the Slovak Academy of Sciences.

3. Bajda, P. (2018). Małe państwo europejskie na arenie międzynarodowej. Polityka zagraniczna Republiki Słowackiej w latach 1993-2016, Kraków-Warsaw, Ośrodek Myśli Politycznej, Wyd. Naukowe UKSW.

4. Bucharest Nine. (2015, November 4). Joint Declaration on Allied Solidarity and Shared Responsibility. https://www.prezident.sk/en/article/joint-declaration-on-allied-solidarityand-shared-responsibility/.

5. Bucharest Nine. (2020, March 19). Joint Declaration on "Allied Solidarity and Shared Responsibility”. http://nato.mae.ro/en/local-news/904.

6. Carothers, T. (2002). The end of the transition paradigm. Journal of Democracy, 13(1), 521.

https://muse.jhu.edu/article/17173/pdf?casa_token=RpxUuaucYsAAAAA:WkqRMZtY4thBWW3LvLfaMLNPbGB7rLOytwnOkYQXoXVQAg V7r4D1bk412upIuLL4ala4LJTplq8.

7. Congressional Research Service (2020, September 28). Russia’s Nord Stream 2 Pipeline: Running in Place. https://crsreports.congress.gov/product/pdf/IF/IF11138.

8. Czaputowicz, J. (2018) Sovereignty. Polish Institute of International Affairs.

9. Dimitrova, A., Mazepus, H., Boroda, M., Chulitskaya, T., Berbeca, V., \&. Parvan, T. (2016). Soft, normative or transformative power: What do the EU's communications with Eastern partners reveal about its influence? EU-STRAT. https://ec.europa.eu/research/participants/documents/downloadPublic?documentIds=0801 66e5b53b9d8f\&appId=PPGMS.

10. Fedorowicz, K. (2017). Transformacja ustrojowa w Armenii w latach 1991-2016. Instytut Wschodni 
https://www.academia.edu/35163231/Transformacja_ustrojowa_w_Armenii_w_latach_1 991_2016_Political_Transformation_in_Armenia_in_1991_2016_now_all_the_text_

11. Fitzmaurice, J. (1998). Politics and Government in the Visegrád Countries: Poland, Hungary, the Czech Republic and Slovakia. Palgrave Macmillan UK.

12. Flenley Paul and Mannin Mike, The European Union and its eastern neighbourhood : Europeanisation and its twenty-first-century contradictions, Manchester : Manchester University Press, 2018.

13. Glaser, C. L. (1994). Realists as Optimists: Cooperation as Self-Help. International Security, 19(3), 51.

14. Grzymski, J. (2016). Powrót do Europy - polski dyskurs. Wyznaczanie perspektywy krytycznej. Warsaw: Oficyna Wydawnicza Uczelni Łazarskiego.

15. Havel, V. (1990, April 9). Speech by the President of the Czechoslovak Socialist Republic Václav Havel at a meeting of representatives of Poland, Czechoslovakia and Hungary, Bratislava, Bratislava. https://archive.vaclavhavel-library.org/File/Show/157123

16. Hettne, B., \& Söderbaum, F. (2000). Theorising the Rise of Regionness. New Political Economy, 5, 457-472.

17. Jakóbik, W. (2018). Nord Stream 2 w polityce zagranicznej rządu RP w latach 2015-2018, Sprawy Międzynarodowe, 74(4), 120-121.

18. Kardaś, S. (2018). Nord Stream 2 w polityce energetycznej Rosji, Sprawy Międzynarodowe, 74(4), 93-111.

19. Kirchner, E. J. (Ed.). (1999). Decentralization and Transition in the Visegrád: Poland, Hungary, the Czech Republic and Slovakia. Palgrave Macmillan UK.

20. Kollmorgen, R. (2013). Theories of Post-communist Transformation. Approaches, Debates, and Problems of Theory Building in the Second Decade of Research. Studies of Transition States and Societies STSS, 5(2).

21. Kowal, P., \& Orzelska-Stączek, A. (2019). Inicjatywa Trójmorza: geneza, cele i funkcjonowanie, Warsaw: ISP PAN.

22. Łoskot-Strachota, A., Bajczuk, R., \& Kardaś, S. (2018, June 18). Nord Stream 2 divides the West, OSW Commentary, https://www.osw.waw.pl/en/publikacje/oswcommentary/2018-06-18/nord-stream-2-divides-west. 
23. Orzelska-Stączek, A. (2015). "Błąd krymski" jako efekt myślenia grupowego? Polska wobec aneksji Krymu, Studia Polityczne, 3.

24. Orzelska-Stączek, A. (2019). Should the Visegrád Group become an international organization given the challenges in international relations? In M. Fiszer, A. Chojan, \& P. Olszewski (Eds.), Place and Role of the Visegrád Group Countries in the European Union, Warsaw: ISP PAN.

25. Orzelska-Stączek, A. (2020). New wave of regional cooperation in Central Europe as a response to new threats, Rocznik Instytutu Europy Środkowo-Wschodniej, 18(1), 79-97. https://doi.org/10.36874/RIESW.2020.1.5

26. Orzelska-Stączek, A., \& Ukielski, P. (2020). Inicjatywa Trójmorza z perspektywy jej uczestników. Warsaw: ISP PAN.

27. Paillard Christophe-Alexandre, " L'Initiative des trois mers, un nouveau terrain d'affrontement majeur russo-américain ", Diplomatie, 2018/1 p. 8-13. URL: https://www.jstor.org/stable/26983082.

28. Pająk-Patkowska, B., \& Rachwał, M. (Eds.). (2016). Hungary and Poland in Times of Political Transition. Selected Issues. Faculty of Political Science and Journalism Adam Mickiewicz University Poznan. http://helwecja.amu.edu.pl/wpcontent/uploads/2013/05/Hungary-and-Poland_tre\%C5\%9B\%C4\%87.pdf.

29. Pantea Ana, « L'initiative « la Ceinture et la Route » dans L'Europe Oriental », Synergies Roumanie, 2018, p. 213-221. URL: https://www.gerflint.fr/Base/Roumanie13/pantea.pdf

30. Pieńkowski, J., Raś, K., Ogrodnik, L., Terlikowski, M., \& Jóźwiak, V. (2018, June 8). The Bucharest 9: Delivering on the Promise to Become the Voice of the Eastern Flank, PISM Policy Paper, 4(164), https://www.pism.pl/publikacje/The_Bucharest_9_Delivering_on_the_Promise_to_Beco me_the_Voice_of_the_Eastern_Flank.

31. Renz, B. (2016). Russia and "hybrid warfare". Contemporary Politics, 22(3). 283-300, DOI: 10.1080/13569775.2016.1201316.

32. Richard Dorota, "Europe centrale: l'Initiative des Trois mers ", Politique étrangère, 2018/2, p. 103-115. DOI: 10.3917/pe.182.0103. URL: https://www.cairn.info/revuepolitique-etrangere-2018-2-page-103.htm. 
33. Riekhoff, A. J. (2004). The transformation of East-Central European Security. Domestic politics, international constraints, and opportunities for policy-makers. Perspectives, 21.

34. Rogozińska, A. (2019). Dziewiątka Bukaresztańska i Idea Trójmorza jako inicjatywy wzmacniające bezpieczeństwo Europy Środkowo-Wschodniej. In M. Banasik (Ed.), Polityka Federacji Rosyjskiej i jej konsekwencje dla bezpieczeństwa międzynarodowego, Warsaw: Difin pp. 313-322.

35. Ruszel, M. (2018). Znaczenie gazociągu Nord Stream 2 dla polityki energetycznej Republiki Federalnej Niemiec. Sprawy Międzynarodowe, 74(4).

36. Secrieru Stanislav, Sinikukka Saari (ed.), The Eastern Partnership a decade on: looking back, thinking ahead, Paris: Institute for Security Studies, 2019.

37. Staniszkis, J. (1999). Post-communism: The Emerging Enigma. Warsaw: Institute of Political Studies, Polish Academy of Sciences.

38. Three Seas Initiative. (2016, August 25). The Joint Statement on the Three Seas Initiative (The Dubrovnik Statement). https://3seas.eu/about/past-summits/dubrovnik-summit-2016

39. Three Seas Initiative. (2018). http://three-seas.eu/wp-content/uploads/2018/09/LIST-OFPRIORITY-INTERCONNECTION-PROJECTS-2018.pdf.

40. Three Seas Initiative. (2019, June 5-6). Joint Declaration of the Fourth Summit of the Three Seas Initiative (Ljubljana). https://three.si/joint-declaration

41. Three Seas Initiative. (2020, October 19). Joint Statement. https://media.voog.com/0000/0046/4166/files/FINAL\%20Three\%20Seas\%20Joint\%20St atement.pdf.

42. Visegrád Group. (1991). Declaration on Cooperation between the Czech and Slovak Federal Republic, the Republic of Poland and the Republic of Hungary in Striving for European Integration. http://www. Visegrádgroup.eu/documents/ Visegrád-declarations/ Visegrád-declaration-110412.

43. Visegrád Group. (2004). Declaration of the Prime Ministers of the Czech Republic, the Republic of Hungary, the Republic of Poland and the Slovak Republic on cooperation of the Visegrád Group countries after their accession to the European Union, 12 May 2004. The Kroměřǐž Declaration. http://www. Visegrádgroup.eu/2004/declaration-of-prime. 
44. Visegrád Group. (2012a, April 18). Declaration of the Visegrád Group - Responsibility for a Strong NATO. http://www. Visegrádgroup.eu/documents/officialstatements/declaration-of-the.

45. Visegrád Group. (2012b, May 4). Joint Communiqué of the Ministers of Defense of the Visegrád Group, Litoměřice. http://www. Visegrádgroup.eu/calendar/2012/jointcommunique-of-the.

46. Visegrád Group. (2014, March 14). Long-Term Vision of the Visegrád Countries on Deepening Their Defense Cooperation. https://www. Visegrádgroup.eu/download.php?docID=253.

47. Visegrád Group. (2015, April 23). Joint Communiqué of the Ministers of Defense of the Visegrád Group met on April 23, 2015 in Tomášov (Slovak Republic). http://www. Visegrádgroup.eu/calendar/2015/joint-communique-of-the.

48. Visegrád Group. (2017, February 2). Joint Communiqué of the Ministers of Defense of the Visegrád Group, Niepołomice. https://www. Visegrádgroup.eu/documents/officialstatements/joint-communique-of-the.

49. Visegrád Group. (2019, June 10). Joint Communiqué of the V4 Defense Ministers, Piešt'any. https://www. Visegrádgroup.eu/download.php?docID=419

50. Walt, S. (2010). Realism and Security. (Published online: December 22, 2017). https://doi.org/10.1093/acrefore/9780190846626.013.286, https://oxfordre.com/internationalstudies/view/10.1093/acrefore/9780190846626.001.000 1/acrefore-9780190846626-e-286.

51. Webber, D. (2016). Declining power Europe: The evolution of the European Union's world power in the early 21st century. European Review of International Studies, 3(1), 31-52. https://www.jstor.org/stable/26593546.

52. Zachová, A. et al. (2018, July 23). Visegrád nations united against mandatory relocation quotas. https://www.euractiv.com/section/justice-home-affairs/news/ Visegrád-nationsunited-against-mandatory-relocation-quotas/.

53. Zając, J. (2016). Poland's Security Policy: The West, Russia, and the Changing International Order. London: Palgrave. 